\title{
Jaundice following cardiopulmonary bypass
}

\author{
JAMES S. ROBINSON,F.R. COLE ${ }^{1}, P$. G I BSON, \\ A N D J . A. S I M P S O N \\ From the Thoracic Surgery Unit and the Department of Biochemistry, Royal Perth Hospital, Perth, \\ Western Australia
}

Serial liver function tests were performed in 29 adult patients following cardiopulmonary bypass for various open-heart procedures. In 22 patients there was a rise in serum bilirubin above $1.5 \mathrm{mg} . / 100 \mathrm{ml}$., with clinical jaundice in 19 and bilirubinuria in 15 patients. The incidence of jaundice was related to age, the severity of pre-operative cardiac failure, and the duration of perfusion. Possible mechanisms for jaundice are discussed, and evidence is presented that liver damage may follow extracorporeal circulation.

At the Royal Perth Hospital in 1965 it was noted that some patients undergoing open-heart surgery developed jaundice with bilirubinuria. In order to determine the incidence and nature of this jaundice serial liver function tests were performed subsequently in all patients in whom extracorporeal circulation was used.

\section{CLINICAL MATERIAL}

Twenty-nine patients were studied. The average age was 34 years, the youngest being 14 years and the oldest 57 years. The clinical state of each patient was classified before operation into four grades, with the following criteria: grade I, minor shortness of breath on effort, no clinical evidence of cardiac failure ; grade II, a history of increasing shortness of breath on effort, receiving digitalis and/or diuretic therapy, but no clinical evidence of cardiac failure ; grade III, a history of previous congestive cardiac failure, severe shortness of breath on effort, and unable to perform normal occupation, receiving digitalis and/or diuretic therapy, but no clinical signs of cardiac failure apart from basal crepitations; grade IV, extreme limitation of effort, a chair or bed existence, receiving digitalis and diuretic therapy, and showing clinical signs of cardiac failure, including an elevated jugular venous pressure. The clinical state was assessed as grade I in five, grade II in 10, grade III in seven, and grade IV in seven patients.

Using the Starr-Edwards prosthesis, valve replacement was performed in 19 patients (see Table I). In nine patients surgery was undertaken for

${ }^{1}$ In receipt of a grant (V.103) from the National Heart Foundation of Australia correction of various congenital defects, while in one patient with spontaneous rupture of the mitral chordae tendineae mitral valvuloplasty was performed.

T A B LE I

OPERATIONS PERFORMED IN THE 29 PATIENTS

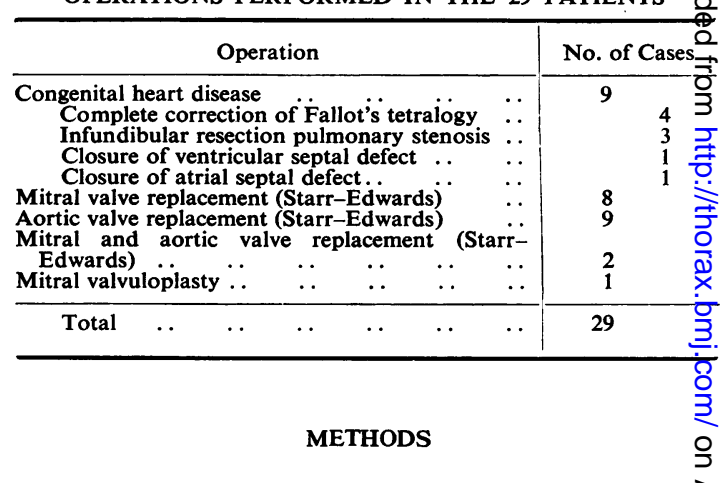

Serum bilirubin, serum aspartate aminotransferase (S.G.O.T.), serum alanine aminotransferase (S.G.P.T. and alkaline phosphatase estimations were performo before operation. The standard method in use at this hospital was employed for each estimation (Beveride, Carter, and Joske, 1963). These tests were repeated on the first, second, fifth, and eighth post-operative da and then every three days until the serum bilirubagn had fallen below $1.5 \mathrm{mg} . / 100 \mathrm{ml}$. In 19 patients samples of blood were taken during perfusion for estimation of the plasma haemoglobin content. On each day of the post-operative period a sample of urine was tested for bilirubin.

Perfusion flow rates of $2.41 . / \mathrm{min} . / \mathrm{m}^{2}$ of boखy surface area were provided from an Ebsray purRp oxygenator (Cohen, Hercus, and Ebsary, 1960). Thate temperature of the perfusate was usually $30^{\circ} \mathrm{C}$., ظू্] 
varied between $22^{\circ} \mathrm{C}$. and $37^{\circ} \mathrm{C}$. The pump was primed with fresh heparinized blood in two patients, while diluted acid-citrate-dextrose (A.C.D.) blood was used in the remaining 27 patients. In four of the latter group the Mayo Clinic diluent for A.C.D. blood was used, consisting of $150 \mathrm{ml}$. of $5 \%$ glucose in $0.2 \%$ saline, $30 \mathrm{mg}$. heparin, $55 \mathrm{ml}$. of a $0.3 \mathrm{M}$ solution of tris-(hydroxymethyl)-aminomethane (T.H.A.M.), $40 \mathrm{ml}$. of concentrated salt-poor human albumin, $5 \mathrm{ml}$. of $10 \%$ calcium chloride, and $1 \mathrm{mEq}$ potassium chloride (Sessler, Taswell, Moffitt, and Kirklin, 1965). In 23 patients we modified this diluent by using $12 \mathrm{mEq}$ sodium bicarbonate instead of T.H.A.M.

In the 27 patients in whom A.C.D. blood was used, epsilon aminocaproic acid was given by intravenous infusion in a total dose of $150 \mathrm{mg} . / \mathrm{kg}$. body weight (Kirklin, 1965). Standard anaesthetic techniques were employed, including premedication with pethidine, 50-100 mg., promethazine, $25 \mathrm{mg}$., and atropine, 0.4 mg.; induction with thiopentone; intubation with suxamethonium; maintenance with D-tubocurare, nitrous oxide, and halothane; and during bypass halothane and hyoscine.

\section{RESULTS}

Unless otherwise specified, the results of biochemical tests given are the peak levels obtained.

The immediate pre-operative tests of liver function were normal in all 29 patients. Following operation there was a rise in serum bilirubin above $1.5 \mathrm{mg} . / 100 \mathrm{ml}$. in 22 patients (76\%), with clinical jaundice in 19 and bilirubinuria in fifteen. The elevation in serum bilirubin ranged from 1.7 to $22.0 \mathrm{mg}$. $/ 100 \mathrm{ml}$., with a mean of $5.0 \mathrm{mg} . / 100$ $\mathrm{ml}$. In 11 of these patients the maximum level of bilirubin ranged from 1.7 to $6.8 \mathrm{mg} . / 100 \mathrm{ml}$. and was attained on the first post-operative day. The time of occurrence of the peak bilirubin level is shown in Table II. The duration of jaundice was proportional to the peak serum bilirubin level (see Fig. 1).

In nine patients there was an abnormal rise in alkaline phosphatase activity, ranging from $14 \cdot 3$ to 35.0 King-Armstrong (K.A.) units. In two

T A B L E I I

DAY OF PEAK BILIRUBIN LEVEL IN 22 PATIENTS WITH HYPERBILIRUBINAEMIA

\begin{tabular}{c|c|c|c}
\hline $\begin{array}{c}\text { Day of Peak } \\
\text { Serum Bilirubin } \\
\text { (22 Patients) }\end{array}$ & No. & \multicolumn{2}{|c}{$\begin{array}{c}\text { Peak Serum Bilirubin } \\
\text { (mg./100 ml.) }\end{array}$} \\
\hline 1 & & Range & Mean \\
\hline 2, 3, and 4 & 11 & $\begin{array}{c}1 \cdot 7-6 \cdot 8 \\
2 \cdot 0-7 \cdot 4\end{array}$ & $3 \cdot 3$ \\
5, 6, and 7 & 6 & $3 \cdot 8$ \\
& 5 & $3 \cdot 6-22 \cdot 0$ & $10 \cdot 3$ \\
\hline
\end{tabular}

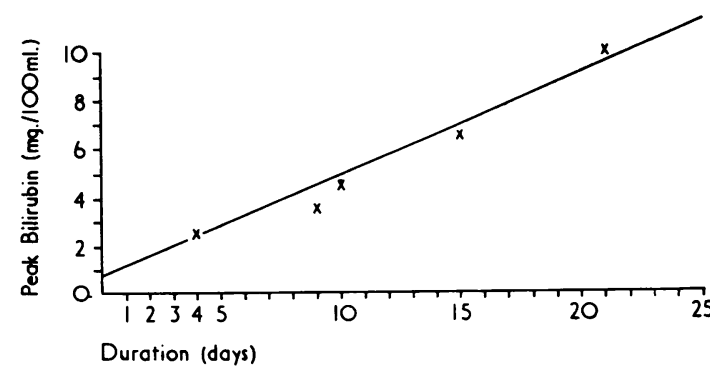

FIG. 1. The relation between severity and duration of jaundice. In 22 survivors the peak serum bilirubin levels, ranging from 1.7 to $12.0 \mathrm{mg} . / 100 \mathrm{ml}$., have been arranged in five groups with similar peak levels, and the mean duration of jaundice for each group has been calculated.

patients the maximum level was greater than 30 K.A. units; one of these patients had active Paget's disease involving the ilium. Six patients with elevated alkaline phosphatase activity were clinically jaundiced and five showed bilirubinuria ; the remaining three patients with levels of $16 \cdot 2$, 16.0 , and $15 \cdot 2$ K.A. units showed maximal serum bilirubin levels of $1.0,1.1$, and $1.8 \mathrm{mg} . / 100 \mathrm{ml}$. respectively (see Table III). Marked jaundice also occurred without elevation of alkaline phosphatase (Table III).

Following operation there was a transient rise in S.G.O.T. above 40 Karmen units in all patients, and, whereas all patients showed a rise in S.G.P.T. activity, in only 18 patients was this above the upper limit of the normal range of 50 Karmen units. The maximum levels of S.G.O.T. and S.G.P.T. attained are shown in Table III. The elevation in S.G.O.T. was at its maximum within the first 48 hours after operation, a pattern similar to that seen in myocardial infarction. There was a bimodal distribution in the time of occurrence of the peak S.G.P.T. level (see Fig. 2). In 10 patients the peak S.G.P.T. level was attained on the first post-operative day, and in five of these patients the elevation was above 50 Karmen units. In 10 patients the peak level of S.G.P.T. occurred about the sixth day, and in nine of these 10 the elevation in S.G.P.T. was above 50 Karmen units.

In patients undergoing pulmonary infundibular resection the mean rise in S.G.O.T. and S.G.P.T. activity was greater than in those not requiring resection of muscle or coronary perfusion. For patients having aortic valve replacement the alteration in S.G.O.T. and S.G.P.T. was closely related to the adequacy of coronary artery perfusion (see Table IV). Coronary artery perfusion was deemed adequate if during perfusion the heart remained beating and there were no electro- 
T A B L E I I I

CLINICAL DATA AND MAXIMUM LEVELS OBTAINED IN CERTAIN BIOCHEMICAL TESTS

\begin{tabular}{|c|c|c|c|c|c|c|c|c|c|c|c|c|}
\hline No. & Age & Grade & Operation & $\begin{array}{l}\text { Per- } \\
\text { fusion } \\
\text { (min.) }\end{array}$ & $\begin{array}{l}\text { Blood } \\
\text { to } \\
\text { Prime } \\
\text { Pump } \\
\text { (units) }\end{array}$ & $\begin{array}{c}\text { Plasma } \\
\text { Haemo- } \\
\text { globin } \\
\text { (mg./ } \\
100 \mathrm{ml} .)\end{array}$ & \begin{tabular}{|} 
Maximum \\
Serum \\
Bilirubin \\
(mg./ \\
$100 \mathrm{ml}$. ) \\
(normal <1 \\
mg./100 ml.)
\end{tabular} & $\begin{array}{c}\text { Bili- } \\
\text { rubin } \\
\text { in } \\
\text { Urine }\end{array}$ & $\begin{array}{c}\text { Maximum } \\
\text { Alkaline } \\
\text { Phosphatase } \\
\text { (K.A. units) } \\
\text { (normal } \\
\text { 3-13 K.A. } \\
\text { units) }\end{array}$ & $\begin{array}{c}\text { Maximum } \\
\text { S.G.O.T. } \\
\text { (Karmen u.) } \\
\text { (normal } \\
0-40 \text { u.) }\end{array}$ & $\begin{array}{l}\text { Maximum } \\
\text { S.G.P.T. } \\
\text { (Karmen u.) } \\
\text { (normal } \\
0-50 \text { u.) }\end{array}$ & 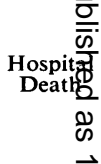 \\
\hline \multicolumn{13}{|c|}{ Infundibular Resection } \\
\hline $\begin{array}{l}1 \\
2 \\
3 \\
4 \\
5 \\
6 \\
7 \\
\end{array}$ & $\begin{array}{l}30 \\
22 \\
23 \\
15 \\
20 \\
16 \\
19\end{array}$ & $\begin{array}{l}\text { I } \\
\text { I } \\
\text { II } \\
\text { II } \\
\text { I } \\
\text { I } \\
\text { II }\end{array}$ & $\begin{array}{l}\text { T.C.F.T. } \\
\text { T.C.F.T. } \\
\text { T.C.F.T. } \\
\text { T.C.F.T. } \\
\text { P.I.R. } \\
\text { P.I.R. } \\
\text { P.I.R. }\end{array}$ & $\begin{array}{r}96 \\
111 \\
110 \\
116 \\
59 \\
70 \\
42 \\
\end{array}$ & $\begin{array}{l}7 \\
8 \\
9 \\
7 \\
7 \\
7 \\
5 \\
\end{array}$ & $\begin{array}{l}\overline{22} \\
\overline{78} \\
27 \\
47 \\
25 \\
\end{array}$ & $\begin{array}{l}0 \cdot 9 \\
2 \cdot 4 \\
2 \cdot 8 \\
3 \cdot 7 \\
1 \cdot 1 \\
1 \cdot 0 \\
1 \cdot 8 \\
\end{array}$ & $\begin{array}{l}\overline{+} \\
- \\
- \\
- \\
-\end{array}$ & $\begin{array}{l}11 \cdot 5 \\
21 \cdot 0 \\
12 \cdot 0 \\
13 \cdot 1 \\
16 \cdot 0 \\
16 \cdot 2 \\
15 \cdot 2\end{array}$ & $\begin{array}{r}102 \\
105 \\
50 \\
104 \\
87 \\
71 \\
173 \\
\end{array}$ & $\begin{array}{r}72 \\
98 \\
46 \\
45 \\
50 \\
44 \\
224\end{array}$ & $+\stackrel{c}{0}$ \\
\hline \multicolumn{13}{|c|}{ Operations not Requiring Infundibular Resection or Coronary Perfusion } \\
\hline $\begin{array}{r}8 \\
9 \\
10 \\
11 \\
12 \\
13 \\
14 \\
15 \\
16 \\
17\end{array}$ & $\begin{array}{l}15 \\
14 \\
50 \\
51 \\
25 \\
22 \\
51 \\
43 \\
36 \\
33\end{array}$ & $\begin{array}{l}\text { I } \\
\text { II } \\
\text { II } \\
\text { II } \\
\text { II } \\
\text { III } \\
\text { III } \\
\text { IV } \\
\text { IV } \\
\text { IV }\end{array}$ & $\begin{array}{l}\text { V.S.D. } \\
\text { A.S.D. } \\
\text { M.V.P. } \\
\text { M.V.R. } \\
\text { M.V.R. } \\
\text { M.V.R. } \\
\text { M.V.R. } \\
\text { M.V.R. } \\
\text { M.V.R. } \\
\text { M.V.R. }\end{array}$ & \begin{tabular}{|r}
63 \\
50 \\
60 \\
84 \\
113 \\
62 \\
75 \\
96 \\
99 \\
81 \\
\end{tabular} & $\begin{array}{l}6 \\
6 \\
7 \\
8 \\
8 \\
7 \\
8 \\
7 \\
8 \\
7 \\
\end{array}$ & $\begin{array}{l}104 \\
16 \\
\overline{36} \\
= \\
\overline{-} \\
29 \\
32 \\
66\end{array}$ & $\begin{array}{r}1 \cdot 7 \\
3 \cdot 3 \\
1 \cdot 0 \\
3.9 \\
1 \cdot 8 \\
1 \cdot 5 \\
12.0 \\
3.6 \\
3.6 \\
7 \cdot 4\end{array}$ & $\begin{array}{l}\overrightarrow{+} \\
\pm \\
- \\
- \\
\overline{+} \\
+ \\
+ \\
+\end{array}$ & $\begin{array}{r}11.8 \\
12.6 \\
11.0 \\
16.6 \\
10.5 \\
11.5 \\
11.8 \\
9.4 \\
35.0 \\
6.1\end{array}$ & $\begin{array}{r}81 \\
108 \\
80 \\
94 \\
96 \\
72 \\
72 \\
104 \\
133 \\
68\end{array}$ & $\begin{array}{r}55 \\
62 \\
38 \\
55 \\
63 \\
31 \\
42 \\
97 \\
113 \\
43\end{array}$ & $\begin{array}{r}\overrightarrow{0} \\
+\quad \overrightarrow{0}\end{array}$ \\
\hline \multicolumn{13}{|c|}{ Adequate Coronary Perfusion } \\
\hline $\begin{array}{l}18 \\
19 \\
20 \\
21 \\
22 \\
23 \\
24 \\
\end{array}$ & $\begin{array}{l}43 \\
52 \\
40 \\
27 \\
40 \\
51 \\
57\end{array}$ & $\begin{array}{l}\text { IV } \\
\text { IV } \\
\text { II } \\
\text { II } \\
\text { III } \\
\text { III } \\
\text { IV }\end{array}$ & $\begin{array}{l}\text { A.+M.V.R. } \\
\text { A.+M.V.R. } \\
\text { A.V.R. } \\
\text { A.V.R. } \\
\text { A.V.R. } \\
\text { A.V.R. } \\
\text { A.V.R. }\end{array}$ & $\begin{array}{l}250 \\
213 \\
161 \\
172 \\
140 \\
156 \\
180 \\
\end{array}$ & $\begin{array}{r}9 \\
10 \\
10 \\
10 \\
9 \\
8 \\
10 \\
\end{array}$ & $\begin{array}{r}36 \\
28 \\
30 \\
160 \\
21 \\
20 \\
28 \\
\end{array}$ & $\begin{array}{r}3 \cdot 0 \\
4 \cdot 8 \\
1 \cdot 0 \\
2 \cdot 0 \\
1 \cdot 1 \\
3 \cdot 1 \\
22 \cdot 0\end{array}$ & $\begin{array}{l}+ \\
+ \\
+ \\
+ \\
+ \\
+\end{array}$ & $\begin{array}{r}11 \cdot 6 \\
14.4 \\
7 \cdot 9 \\
9 \cdot 7 \\
6.6 \\
5 \cdot 8 \\
34.0 \\
\end{array}$ & $\begin{array}{r}95 \\
73 \\
107 \\
140 \\
51 \\
183 \\
60 \\
\end{array}$ & $\begin{array}{r}127 \\
34 \\
102 \\
65 \\
49 \\
228 \\
36 \\
\end{array}$ & $\begin{array}{r}\grave{\partial} \\
+\quad \overline{0}\end{array}$ \\
\hline \multicolumn{13}{|c|}{ Inadequate Coronary Perfusion } \\
\hline $\begin{array}{l}25 \\
26 \\
27 \\
28 \\
\end{array}$ & $\begin{array}{l}28 \\
25 \\
19 \\
53 \\
\end{array}$ & $\begin{array}{l}\text { II } \\
\text { III } \\
\text { III } \\
\text { III } \\
\end{array}$ & $\begin{array}{l}\text { A.V.R. } \\
\text { A.V.R. } \\
\text { A.V.R. } \\
\text { A.V.R. }\end{array}$ & $\begin{array}{l}180 \\
208 \\
190 \\
210 \\
\end{array}$ & $\begin{array}{r}13 \\
7 \\
10 \\
12 \\
\end{array}$ & $\frac{-}{48}$ & $\begin{array}{l}6 \cdot 8 \\
2 \cdot 6 \\
6 \cdot 1 \\
8 \cdot 1 \\
\end{array}$ & $\begin{array}{l}+ \\
+ \\
+ \\
+\end{array}$ & $\begin{array}{r}7 \cdot 4 \\
9 \cdot 1 \\
14 \cdot 3 \\
7 \cdot 5 \\
\end{array}$ & $\begin{array}{l}167 \\
194 \\
213 \\
103 \\
\end{array}$ & $\begin{array}{l}210 \\
190 \\
240 \\
216\end{array}$ & $\begin{array}{l}+ \\
+ \\
\end{array}$ \\
\hline \multicolumn{13}{|c|}{ Ligation of Circumflex Coronary Artery } \\
\hline 29 & 19 & IV & M.V.R. & 95 & 9 & - & $4 \cdot 1$ & + & $13 \cdot 2$ & 170 & 240 & + \\
\hline
\end{tabular}

T.C.F.T. = Total correction Fallot's tetralogy. P.I.R. = Pulmonary infundibular resection. V.S.D. $=$ Closure of ventricular sept@ defect. A.S.D. = Closure of atrial septal defect. M.V.P. = Mitral valvuloplasty. M.V.R. $=$ Mitral valve replacement. A. + M.V.R. Aortic and mitral valve replacement. A.V.R. = Aortic valve replacement.

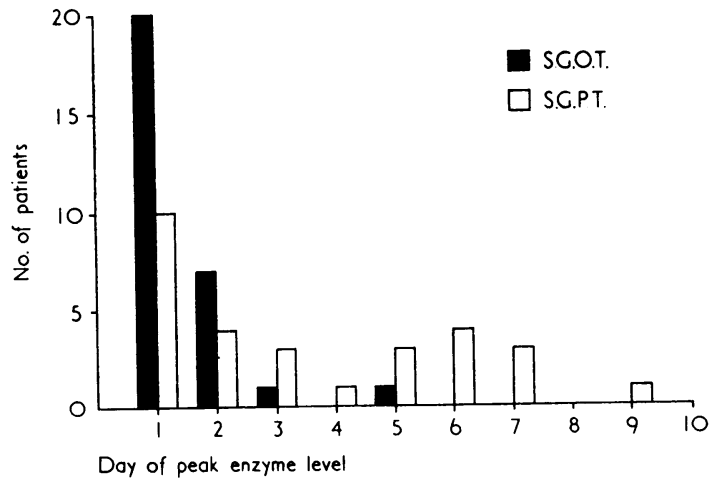

FIG. 2. In the majority of patients the peak S.G.O.T. level was attained within the first 48 hours after operation, but there was a bimodal distribution to the time of development of the peak S.G.P.T. level. cardiographic ST-T changes of myocardia ischaemia (Clarke, 1965). In one patient during mitral valve replacement the left coronary arterø was inadvertently ligated, and the post-operative rise in S.G.O.T. and S.G.P.T. activity parallele the mean rise in patients with inadequate coronar perfusion during aortic valve replacement (Table IV).

Clinical jaundice with bilirubinuria occurred i all seven patients with grade IV pre-operative cardiac failure. Clinical jaundice was present if five of the seven patients with grade III cardiac failure, in six of the 10 classified as grade II, an\$ in one patient classified as grade I. There was a progressive increase in the mean peak serur bilirubin level for each of the four grades of cardiac failure (see Table V). Two patients class $\frac{f}{0}$ fied as grade II and one as grade I showed serum bilirubin levels of $1.8,1.8$, and $1.7 \mathrm{mg} . / 100 \mathrm{~m}$ 
T A B L E I V

RANGE AND MEAN S.G.O.T. AND S.G.P.T. VALUES IN RELATION TO OPERATIVE RESECTION OR CORONARY PERFUSION

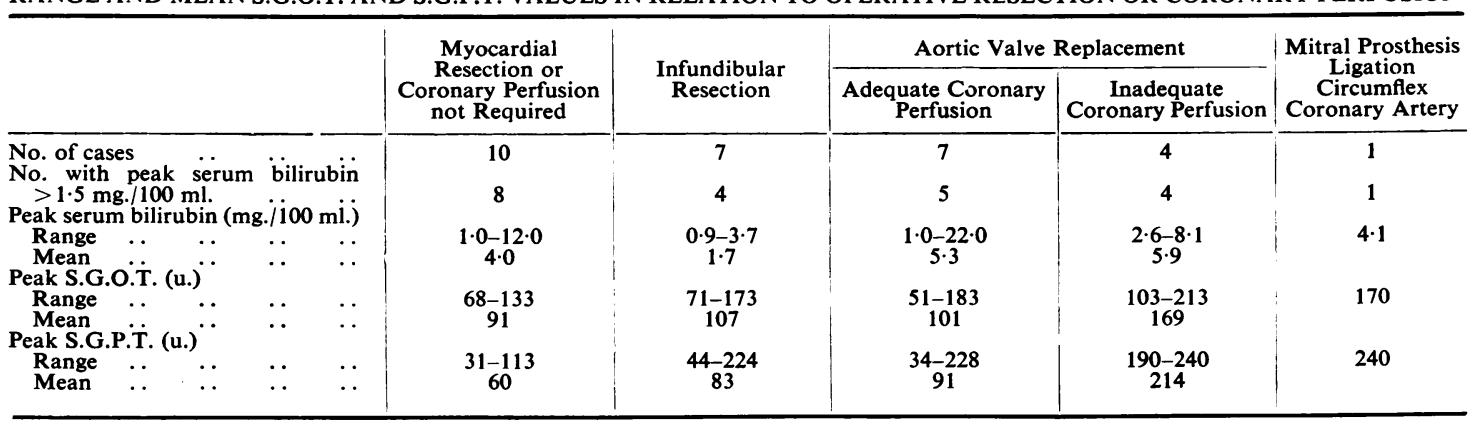

T A B L E V

RELATIONSHIP BETWEEN SEVERITY OF PRE-OPERATIVE CARDIAC FAILURE AND INCIDENCE OF CLINICAL

\begin{tabular}{|c|c|c|c|c|}
\hline $\begin{array}{l}\text { Grade of } \\
\text { Cardiac } \\
\text { Failure }\end{array}$ & No. & $\begin{array}{l}\text { No. with } \\
\text { Clinical } \\
\text { Jaundice }\end{array}$ & $\begin{array}{c}\text { No. with } \\
\text { Bilirubin- } \\
\text { uria }\end{array}$ & $\begin{array}{c}\text { Range and } \\
\text { Mean Peak } \\
\text { Serum Bilirubin } \\
\text { (mg./100 ml.) }\end{array}$ \\
\hline I & 5 & 1 & 1 & $0.9-2.4$ \\
\hline II & 10 & 6 & 3 & $1.0-6 \cdot 8$ \\
\hline III & 7 & 5 & 4 & $1 \cdot 1-12 \cdot 0$ \\
\hline IV & 7 & 7 & 7 & $\begin{array}{c}3.0-22.0 \\
(6.9)\end{array}$ \\
\hline
\end{tabular}

T A B L E V I

INFLUENCE OF AGE ON DEVELOPMENT OF JAUNDICE

\begin{tabular}{|c|c|c|c|c|c|c|c|c|}
\hline \multirow{2}{*}{$\begin{array}{c}\text { Age } \\
\text { Group } \\
\text { (years) }\end{array}$} & \multirow[t]{2}{*}{ No. } & \multirow{2}{*}{$\begin{array}{l}\text { No. with } \\
\text { Clinical } \\
\text { Jaundice }\end{array}$} & \multirow{2}{*}{$\begin{array}{c}\text { No. with } \\
\text { Bilirubin- } \\
\text { uria }\end{array}$} & \multicolumn{4}{|c|}{$\begin{array}{c}\text { Clinical } \\
\text { Grade }\end{array}$} & \multirow{2}{*}{$\begin{array}{c}\text { Range and } \\
\text { Mean Peak } \\
\text { Serum } \\
\text { Bilirubin } \\
\text { (mg.l } \\
100 \mathrm{ml} \text {.) }\end{array}$} \\
\hline & & & & I & II & III & IV & \\
\hline $14-20$ & 8 & 4 & 3 & 3 & 3 & 1 & 1 & $1 \cdot 0-6 \cdot 1$ \\
\hline $21-30$ & 8 & 5 & 3 & 2 & 4 & 2 & & $0.9-6.8$ \\
\hline $31-40$ & 4 & 2 & 2 & & 1 & 1 & 2 & $\begin{array}{l}(2.6) \\
1.0-7 \cdot 4\end{array}$ \\
\hline $41-50$ & 3 & 2 & 2 & & 1 & & 2 & $1.0-3.6$ \\
\hline $51-60$ & 6 & 6 & 5 & & 1 & 3 & 2 & $\begin{array}{c}3 \cdot 1-22.0 \\
(8.9)\end{array}$ \\
\hline
\end{tabular}

respectively; however, there was no evidence of jaundice and no bilirubinuria.

The incidence of clinical jaundice and bilirubinuria in relation to age is shown in Table VI. All six patients over the age of 50 years developed clinical jaundice; bilirubinuria occurred in five. Otherwise, there was little relationship between age and the occurrence of jaundice.

Clinical jaundice occurred in all patients in whom the perfusion time was over 180 minutes. The relationship between the duration of perfu-
T A B L E V I I

RELATIONSHIP BETWEEN INCIDENCE OF JAUNDICE WITH BILIRUBINURIA AND DURATION OF PERFUSION

\begin{tabular}{|c|c|c|c|c|}
\hline $\begin{array}{l}\text { Duration of } \\
\text { Perfusion } \\
\text { (min.) }\end{array}$ & $\begin{array}{c}\text { No. of } \\
\text { Patients }\end{array}$ & $\begin{array}{l}\text { No. with } \\
\text { Peak } \\
\text { Serum } \\
\text { Bilirubin } \\
>1.5 \mathrm{mg} . / \\
100 \mathrm{ml} .\end{array}$ & $\begin{array}{l}\text { No. with } \\
\text { Bilirubin- } \\
\text { uria }\end{array}$ & $\begin{array}{c}\text { Range and } \\
\text { Mean Peak } \\
\text { Serum } \\
\text { Bilirubin } \\
\text { (mg./100 ml.) }\end{array}$ \\
\hline Up to 90 & 10 & 6 & 3 & $1 \cdot 0-12 \cdot 0$ \\
\hline $90-180$ & 14 & 11 & 8 & $0.9-22.0$ \\
\hline$>180$ & 5 & 5 & 4 & $\begin{array}{c}2 \cdot 6-8 \cdot 1 \\
(4 \cdot 9)\end{array}$ \\
\hline
\end{tabular}

T A B L E V I I I

RELATIONSHIP BETWEEN INCIDENCE OF JAUNDICE AND UNITS OF BLOOD

\begin{tabular}{c|c|c}
\hline No. of Units of Blood & No. of Cases & $\begin{array}{c}\text { No. with Peak } \\
\text { Serum Biliubin } \\
>1.5 \mathrm{mg} . / 100 \mathrm{ml} .\end{array}$ \\
\hline $5-6$ & 3 & 0 \\
$7-8$ & 15 & 5 \\
$9-10$ & 9 & 2 \\
$11-13$ & 2 & 0 \\
\hline
\end{tabular}

sion, serum bilirubin, and bilirubinuria is shown in Table VII. The plasma haemoglobin level during perfusion showed no relationship to the degree of post-operative jaundice or the duration of perfusion (see Table III). Clinical jaundice occurred in both patients in whom heparinized blood was used to prime the pump, and neither of these patients received epsilon aminocaproic acid. In all four patients in whom T.H.A.M. was incorporated in the A.C.D. diluent clinical jaundice developed, three showing bilirubinuria. There did not appear to be any significant relationship between the incidence of jaundice and the number of units of blood required to prime and 'top up' the pump (see Table VIII).

There were six hospital deaths (see Table III). All six patients were clinically jaundiced, with 
peak serum bilirubin levels ranging from $2 \cdot 8$ to $8.1 \mathrm{mg}$. $/ 100 \mathrm{ml}$. (mean $5.4 \mathrm{mg} . / 100 \mathrm{ml}$.). Jaundice was associated with bilirubinuria in five of these patients, and at necropsy all five showed microscopic centrilobular hepatic necrosis. It is of interest, but doubtful significance, that these five patients all received epsilon aminocaproic acid, whereas the sixth patient did not receive this treatment, and, although he was clinically jaundiced, there was no bilirubinuria and at necropsy no evidence of hepatic necrosis.

\section{DISCUSSION}

Kirgsley (1966) studied 19 patients undergoing open-heart surgery with profound hypothermia and extracorporeal circulation. In all 19 patients there was a rise in serum bilirubin, and in 10 clinical jaundice. The present study has confirmed these findings, 22 out of 29 patients showing a rise in serum bilirubin above $1.5 \mathrm{mg} . / 100 \mathrm{ml}$. and 19 having clinical jaundice. The presence of bilirubinuria in 15 of the jaundiced patients suggests that in these patients the mechanism for excretion of conjugated bilirubin was deranged. Bilirubinuria was not present in the remaining seven patients with hyperbilirubinaemia ; in three, the peak serum bilirubin level was less than $2 \cdot 0$ mg./100 ml., while four had clinical jaundice with serum bilirubin levels ranging from 2.6 to 3.9 mg./100 ml. If in these four patients hyperbilirubinaemia was mainly due to conjugated bilirubin, bilirubinuria would be expected. Therefore it appears that two mechanisms were responsible for hyperbilirubinaemia, one hepatic and the other haemolytic.

If intrahepatic or extrahepatic biliary obstruction was responsible for hyperbilirubinaemia, a correlation between serum bilirubin levels, bilirubinuria, and serum alkaline phosphatase might have been expected. No such correlation was evident (see Table III). In four patients (cases 14, 17,19 , and 24 , see Table III), jaundice, with peak serum bilirubin levels of $12 \cdot 0,7 \cdot 4,4 \cdot 8$, and $22.0 \mathrm{mg} . / 100 \mathrm{ml}$. respectively, was accompanied by bilirubinuria. In each patient there was a mild elevation in S.G.O.T. to $72,68,73$, and 60 Karmen units respectively, but in none of these patients did the S.G.P.T. rise above $50 \mathrm{Karmen}$ units. These changes suggest an obstructive type of jaundice. However, in two patients (cases 14 and 17) the serum alkaline phosphatase was not elevated, while in one patient (case 19) there was a rise to $14.4 \mathrm{~K}$.A. units. In the fourth patient the serum alkaline phosphatase rose from a pre-operative level of 10.3 to 34.0 K.A. units in the post operative period. However, this patient also has active Paget's disease involving the ilium, and thi may have contributed to the changes in alkaline्ల phosphatase.

Alteration of liver function and liver damage may follow cardiopulmonary bypass. Immediately after extracorporeal circulation in dogs there is depression of hepatic bromsulphalein extraction (Andersen, Norberg, and Senning, 1958). Snyder Barnard, Varco, and Lillehei (1958) demonstrated a transient rise in S.G.O.T. following open-hearit surgery; they considered that hepatic change\& during perfusion were the major source of thisis enzyme, but they did not measure liver specific enzymes. The presence of liver damage following profound hypothermia and extracorporeal circulation has been demonstrated by estimation of liver specific enzymes, isocitric dehydrogenase an* lactic dehydrogenase isoenzyme 1 (Kingsleye 1966). In dogs undergoing extracorporeal circulag tion there was no difference in the post-operative rise in S.G.O.T. whether profound hypothermi or normothermia was used (Dunlop and Curnows 1962).

In the present study liver cell damage did prê sumably contribute to the changes in S.G.O.T. and S.G.P.T., but myocardial cell damage must have played a part also. A myocardial contribution is suggested by the high S.G.O.T. levels in the patients with inadequate coronary artery perfusion and in the patient with inadvertent ligatio $\overline{8}$ of the left circumflex coronary artery. Howeve in four of these five patients the usual S.G.O.T. S.G.P.T. ratio was reversed, the peak S.G.P. being greater than the peak S.G.O.T. Three of these patients (cases 25, 28, and 29) died in severis cardiac failure, and one (case 27) was re-explore because of a haemopericardium with cardiae tamponade. Hepatic venous congestion was pre sent in these four patients, and this may have contributed to the marked elevation in S.G.P. W In three other patients (cases 7, 18, and 23) the peak S.G.P.T. was greater than the peas S.G.O.T. ; in two of these patients these changes remain unexplained, while the third (case 23) died in severe cardiac failure, and again hepatic venots congestion or hepatic anoxia may have been re sponsible for the elevation of S.G.P.T. The lack of organ specificity with S.G.O.T. and S.G.P.T. T. does not allow a quantitative estimate of the com tribution of hepatic and myocardial changes.

Aberration of liver function tests may follow congestive cardiac failure (Felder, Mund, and Parker, 1950). Congestive cardiac failure leads 
anoxia of the centrilobular liver cells and may result in centrilobular hepatic necrosis (Calderon and Alexander, 1966). Similar pathological changes were found in five of our patients at necropsy.

Although routine tests of liver function were normal prior to operation, severe cardiac failure predisposed patients to the development of clinical jaundice after cardiopulmonary bypass. Similar findings were reported by Kingsley (1966). Age in excess of 50 years and a perfusion of more than 180 minutes were also invariably accompanied by clinical jaundice. It is conceivable that these factors, age, severity of cardiac failure, and duration of perfusion, have hepatic anoxia as the common pathway to the production of jaundice and liver damage.

The results of this study suggest that there are two and possibly three mechanisms in the production of jaundice after open-heart surgery-one, a hepatocellular mechanism, another, haemolysis, and the possible third, biliary obstruction. Further investigation is planned to elucidate this problem.
We wish to thank all members of the cardiac surgical team for their assistance, and Dr. R. A. Joske and Dr. D. H. Curnow for their guidance and criticism.

\section{REFERENCES}

Andersen, M. N., Norberg, B., and Senning, $\AA$. (1958). Studies of liver function during extracorporeal circulation with low flow rate. Surgery, 43, 397.

Beveridge, B. R., Carter, G. M., and Joske, R. A. (1963). A comparative study of some liver function tests in the differential diagnosis of jaundice. Med. J. Aust., 1, 346.

Calderon, D. C., and Alexander, S. (1966). The liver in congestive heart failure. Med. Clin. N. Amer., 50, 487.

Clarke, F. B. (1965). Monitoring of coronary artery perfusion. $J$. thorac. cardiovasc. Surg., 49,931.

Cohen, D., Hercus, V., and Ebsary, V. R. (1960). The Royal Alexandra Hospital for Children heart-lung machine. Med. J. Aust., 2, 734.

Dunlop, M., and Curnow, D. H. (1962). Transaminase levels in the normal dog, and the effect of profound hypothermia. Ibid., 2, 292.

Felder, L., Mund, A., and Parker, J. G. (1950). Liver function tests in chronic congestive heart failure. Circulation, 2, 286.

Kingsley, D. P. E. (1966). Hepatic damage following profound hypothermia and extracorporeal circulation in man. Thorax, 21, 91.

Kirklin, J. W. (1965). Organ function during and after open heart surgery. N.Z. med. J., 64, Suppl., p. 1.

Sessler, A. D., Taswell, H. F., Moffitt, E. A., and Kirklin, J. W. (1965). Heparinized versus acid-citrate-dextrose blood for cardiopulmonary bypass. Mayo Clin. Proc., 40, 859.

Snyder, D. D., Barnard, C. N., Varco, R. L., and Lillehei, C. W. (1958). Serum transaminase patterns following intracardiac surgery. Surgery, 44, 1083. 